\title{
NILAI-NILAI KEARIFAN LOKAL UNTUK MENUMBUHKEMBANGKAN LITERASI BUDAYA DI SEKOLAH DASAR
}

\author{
Desyandri \\ Fakultas Ilmu Pendidikan, Universitas Negeri Padang \\ Jalan Prof. Dr. Hamka Air Tawar Padang, Sumatera Barat \\ email: desyandri@fip.unp.ac.id
}

\begin{abstract}
This study aims to revealing and applying the local wisdom value, especially on Minang songs, for cultural literacy growth in elementary school to avoided of cultural depletion. The research uses hermeneutic analysis methods to reveal the values of local wisdom on Minang songs and ethnographic methods to photograph the process of implicating those values. The results of the study explain that the learning steps are done by collaborating and inserting the local wisdom values as means as cultural literacy with (1) appreciation; (2) imitating ; (3) express the song; (4) identifying and understanding; and (5) implementing the meaning of local wisdom.
\end{abstract}

Keywords: local wisdom, Minang song, cultural literacy at primary school

\begin{abstract}
Abstrak: Penelitian ini bertujuan untuk mengungkap dan menerapkan nilai-nilai kearifan lokal yang terkandung pada lagu daerah khususnya lagu-lagu Minang dalam menumbuhkembangkan literasi budaya di SD agar terhindar dari ketercerabutan dari budaya. Metode penelitian menggunakan analisis hermenutik untuk mengungkap nilai-nilai kearifan lokal lagu-lagu Minang dan metode etnografi untuk memotret proses pengimplentasian nilai-nilai tersebut. Hasil penelitian menjelaskan bahwa langkah pembelajaran dilakukan dengan dengan menggabungkan dan menyisipkan nilai-nilai kearifan lokal sebagai sarana literasi budaya dengan cara: (1) Apresiasi; (2) Menirukan lagu; (3) mengekspresikan lagu; (4) Mengidentifikasi dan memahami makna nilai-nilai kearifan lokal; dan (5) Mengimplementasikan nilai-nilai kearifan lokal.
\end{abstract}

Kata kunci: kearifan lokal, lagu Minang, literasi budaya SD

Bangsa yang besar ditandai dengan masyarakatnya yang literat, yang memiliki peradaban tinggi, dan aktif memajukan masyarakat dunia. Keberliterasian dalam konteks ini bukan hanya masalah bagaimana suatu bangsa bebas dari buta aksara, melainkan juga yang lebih penting, bagaimana warga bangsa memiliki kecakapan hidup agar mampu bersaing dan bersanding dengan bangsa lain untuk menciptakan kesejahteraan dunia (Effendy, 2017: 6). Deklarasi Praha tahun 2003 menyebutkan bahwa literasi juga mencakup bagaimana seseorang berkomunikasi dalam masyarakat. Literasi juga bermakna praktik dan hubungan sosial yang terkait dengan pengetahuan, bahasa,dan budaya (UNESCO, 2003 dalam
Kemendikbud, 2016). Di samping itu, World Economic Forum 2015 dalam Kemendikbud (2017) mengemukakan bahwa literasi menjadi sangat penting tidak hanya bagi peserta didik, tetapi juga bagi orang tua dan seluruh warga masyarakat. Enam literasi dasar tersebut mencakup literasi baca tulis, literasi numerasi, literasisains, literasi digital, literasi finansial, dan literasi budaya dan kewargaan. Di samping itu juga dijelaskan bahwa literasi adalah kemampuan memahami teks, angka, dan simbol tertulis baik cetak maupun digital dalam berbagai bidang dan menggunakannya untuk meningkatkan kualitas hidup baik personal maupun sosial dan literasi budaya adalah kemampuan memahami kebu- 
dayaan sebagai identitas bangsa dan warga negara sebagai unsur masyarakat yang mampu melaksanakan hak dan kewajiban untuk meningkatkan kualitas hidupnya dan orang lain.

Berkaitan dengan itu, salah satu kecakapan hidup yang harus dimiliki peserta didik di abad 21 ini dalam menghadapi pesatnya perkembangan Ilmu Pengetahuan, Teknologi, dan Seni (IPTEKS) serta pengaruh globalisasi yang ditandai dengan masuknya budaya-budaya luar yang belum tentu sesuai dengan budaya lokal adalah literasibudaya dan kewargaan. Literasi budaya melebihi kemampuan "baca-tulis". Litrerasi budaya dapat didefinisikan sebagai jaringan informasi yang dimiliki oleh pembaca kompeten, sebagai dasar informasi yang melekat di pikiran dan dipahami, memperoleh intinya, memahami implikasinya, menghubungkan apa yang mereka baca dengan konteks yang tidak tertulis yang memberi makna terhadap bacaan. Hirsc (dalam Hoffman, 1991:2) menjelaskan bahwa literasi budaya adalah, "The network of information that competent readers possess. It is the background information, stored in their minds, that enables them to take up a newspaper and read it with an adequate level of comprehension, getting the point, grasping the implications...".

Negara Kesatuan Republik Indonesia (NKRI) terkenal dengan kemajemukannya dan merupakan negara dengan keanekaragaman etnis budaya dan agama. Penduduk Indonesia terdiri dari berbagai macam suku bangsa dengan keunikan identitas budayanya sendiri. Dilihat dari segi geografis Indonesia merupakan negara kepulauan dengan penduduk yang tersebar di daerah pegunungan, pesisir pantai dengan karakteristik lingkungan yang berbeda satu sama lain dan sekaligus menggambarkan keberagaman kearifan lokal menurut budayanya masingmasing. Kartawinata (2011:ix) mengemukakan bahwa dalam pengertian kebahasaan kearifan lokal, berarti kearifan setempat (local wisdom) yang dapat dipahami sebagai gagasan-gagasan lokal yang bersifat bijaksana, penuh kearifan, bernilai yang tertanam dan diikuti oleh warga masyarakatnya. Dalam konsep antropologi, kearifan lokal dikenal pula sebagai pengetahuan setempat (indigenous or local knowledge), atau kecerdasan setempat (local genius), yang menjadi dasar identitas kebudayaan (cultural identity).

Salah satu budaya tersebut adalah adat Minangkabau. Adat Minangkabau sebagai bagian dari khazanah budaya nasional memiliki keunikan tersendiri dan merupakan aset Provinsi Sumatera Barat. Adat Minangkabau bermanfaat bagi bangsa dan negara terutama bagi etnis Minang sendiri me-nuju masyarakat yang maju, beradat, berbudaya tinggi, dan berkarakter dalam mengisi pembangunan bangsa dalam wadah Negara Kesatuan Republik Indonesia (NKRI). Adat Minangkabau dirancang berdasarkan akal-budi (perpaduan antara pikiran dan perasaan untuk menimbang baik dan buruk mengacu pada alam takambang jadi guru, raso jo pareso (rasa/karsa dengan periksa/kontrol) yang menurut alua jo patuik (alur dan patut) akan melahirkan sikap dan perilaku yang baik dengan mempertimbangkan perasaan malu dan sopan, agar memunculkan kearifan pengetahuan dan berperilaku sebagai manusia dalam kehidupan sosial yang beradab (Zainuddin, 2010:106). Adat Minangkabau memberikan acuan atau pedoman nilai-nilai kearifan lokal yang bersumberkan dari akal-budi dalam menjalani kehidupan, sehingga melahirkan tindakan dan perilaku masyarakat yang mencerminkan karakter khas orang Minangkabau. Dengan kata lain, nilai-nilai adat tersebut dapat diartikan sebagai kearifan lokal yang dimiliki oleh budaya Minangkabau dan bertujuan untuk mengedukasi masyarakat agar melek budaya serta menampilkan perilaku yang beradat, beradab, dan berkarakter.

Nilai-nilai adat sebagai nilai-nilai kearifan lokal Minangkabau juga terkristalisasi pada keseniannya, yaitu lagu-lagu Minang. Hal ini menunjukkan bahwa lagu-lagu Minang memiliki nilai-nilai kearifan lokal untuk membantu tercapainya tujuan adat budaya Minangkabau. Desyandri (2016: 46) mengemukakan bahwa lagu Minang merupakan nilai-nilai kearifan lokal yang sangat penting dan bermanfaat sebagai tuntunan, nasehat, dan mendidik orang Minang agar berperilaku sesuai norma adat Minangkabau, serta dapat dijadikan sebagai sarana literasi budaya bagi peserta didik di SD. Nilai-nilai tersebut diantaranya: cinto ranah Minang, kesadaran dan harga diri, kepedulian dan tanggung jawab, dan kewaspadaan, serta disiplin. Kemendibud (2017: 3) mengemukakan bahwa Literasi budaya merupakan kemampuan dalam memahami dan bersikap terhadap kebudayaan Indonesia sebagai identitas bangsa.

Kondisi ini berbanding terbalik dengan realitas yang ada sekarang ini. Melihat kondisi ideal pendidikan sebagai upaya normatif dalam perber- 
dayaan dan pembudayaan khususnya di wilayah Minangkabau atau Sumatera Barat pada kondisi sekarang, secara umum masih menyisakan berbagai permasalahan, seperti tercerabutnya orang Minang dari budayanya sendiri, seperti yang dikemukakan Naim (2003) bahwa permasalahan besar yang dihadapi masyarakat Minangkabau adalah hilangnya hal yang paling berharga dari diri mereka, yaitu jati diri. Jati diri yang dimaksudkan adalah nilai-nilai adat Minangkabau yang menjadi ajaran dan tujuan adat Minangkabau. Permasalahan ini menggambarkan bahwa pendidikan sebagai proses pembudayaan dalam upaya menanamkan nilai-nilai positif adat Minangkabau dan nilai-nilai edukatif lagu-lagu Minang khususnya di wilayah Minangkabau atau Sumatera Barat selama ini belum terlaksana dengan optimal. Permasalahan tersebut diperparah lagi dengan bergulirnya arus globalisasi. Globalisasi yang terjadi pada abad 21. Dampak globalisasi secara langsung atau tidak langsung telah membawa wajah baru dalam penampilan adat budaya (Sairin, 2003). Masyarakat Minangkabau yang semakin kuat berinteraksi dengan masyarakat dunia pada saat sekarang tidak terhindarkan menyerap berbagai nilai budaya dari ranah budaya universal (Amir, 2007). Masyarakat Minangkabau mengalami kegoncangan budaya yang menyeret generasi muda untuk mencari jalan hidupnya sendiri-sendiri dengan kontrol budaya yang lemah (Sairin, 2003).

Realitas yang terjadi di lapangan menunjukkan bahwa secara kuantitas seiring dengan perkembangan zaman memperlihatkan kondisi perilaku peserta didik dan masyarakat yang semakin mengkhawatirkan, seperti berita yang dirilis Harian Padang Ekspres 29 April 2013 bahwa satu per satu peserta didik di Kota padang tersandung kasus hukum, baik yang disebabkan tawuran antar pelajar, pencurian, maupun kasus kepemilikian narkoba. Selain itu, Riadi (2014) dilansir Republika memberitakan bahwa hari kelulusan diwarnai dengan tawuran pelajar di Ruang Terbuka Hijau (RTH) Imam Bonjol Kota Padang. Fakta ini menggambarkan bahwa proses pendidikan belum berjalan dengan optimal dan menjauh dari nilai-nilai adat Minangkabau. Kondisi sebelumnya sangat berkaitan dengan pembelajaran seni musik khususnya pembelajaran tentang lagu daerah setempat yang dilaksakan di sekolah-sekolah. Realita pembelajaran seni musik di sekolah dasar, khususnya di Kota Padang ditengarai belum optimal. Berikut dipaparkan hasil pengamatan dan pengalaman peneliti dari tahun 2006 hingga sekarang dalam membimbing maha calon guru SD yang dikombinasikan dengan hasil studi pendahuluan (Januari hingga Juni 2017) bahwa proses pembelajaranbelum optimal dan lebih berorientasi pada penguasaan kemampuan intelektual semata, mengabaikan prosespelestarian dan internalisasi nilai-nilai kearifan lokal adat Minangkabau yang terkandung dalam lagu-lagu Minang, sehingga pembelajaran hanya dijadikan sebagai hiburan semata dan memperkaya pengetahuantetapi miskin nilai-nilai. Tilaar (2010:218) mengemukakan bahwa intelektualisme yang telah menjadi ciri pendidikan nasional telah mengasingkan budaya dan apresiasi budaya dalam pendidikan nasional. Bukan berarti bahwa kognisi tidak diperlukan dalam pengembangan kepribadian manusia.

Pandangan Tilaar terlihat dalam realita pembelajaran seni musik di sekolah-sekolah. Pembelajaran didominasi fungsi hiburan semata, pemberian materi dalam bentuk hafalan musik/lagu-lagu Minang, mengekplorasi kandungan nilai-nilai edukatif secara garis besar tanpa dilanjutkan dengan pengimplementasian dan pembudayaan nilai-nilai tersebut dalam kehidupan sehari-hari peserta didik. Bahkan sekolah-sekolah di Kota Padang terlihat mulai meninggalkan lagu-lagu Minang, sehingga nilai-nilai kearifan lokal lagu-lagu Minang tidak lagi difungsikan sebagaimana mestinya. Hal ini dapat dibuktikan dengan sedikitnya lagu-lagu Minang yang dibelajarkan di sekolah dan kebanyakan peserta didik kurang mengetahui lagu-lagu Minang. Seharusnya pendidikan seni musik dapat mengembangkan rasa keindahan, kreativitas, dan kepribadian, serta menjadikan peserta didik lebih produktif dan berbudaya (Astuti: 2010:5). Permasalahan ini dapat menyebabkan munculnya kecenderungan perilaku dan karakter peserta didik yang tidak beradat/tidak beradab, seperti: kurangnya rasa menghargai dan menghormati orang lain, kurangnya sopan-santun, lebih mementingkan diri sendiri, serta kurang peduli dengan adat atau budaya daerah mereka sendiri. Perilaku negatif ini, jika dibiarkan terus-menerus mengakibatkan tercerabutnya peserta didik dari budayanya sendiri.Orang Minang yang tidak tahu dengan adat Minangkabau. Seperti kata pepatah Minang, "Lah lupo kacang jo kuliknyo", maksud pepatah ini menggambarkan seseorang yang telah lupa dengan adat budayanya sendiri. 
Berdasarkan permasalahan yang diungkap sebelumnya dan untuk menghindari ketercerabutan budaya, diperlukan upaya pengimplementasian nilai-nilai kearifan lokal Minangkabau yang terkandung dalam lagu-lagu Minang sebagai sarana untuk menumbuhkembangkan gerakan literasi budaya menuju peserta didik yang beradat, beradab, dan berkarakter. Tujuan penelitian adalah mengidentifikasi nilai-nilai kearifan lokal lagu-lagu Minang dan mendeskripsikan proses dan langkah pembelajaran dalam upaya pembudayaan dan pengimplementasian nilai-nilai kearifan lokal Minangkabau untuk menumbuhkembangkan literasi budaya peserta didik.

\section{METODE}

Fokus penelitian ini adalah untuk mengidentifikasi nilai-nilai kearifan lokal dan memotret proses dan langkah pembelajaran seni musik di SD yang berkaitan dengan pembudayaan dan pengimplementasian nilai-nilai kearifan lokal lagu-lagu Minang sebagai sarana literasi budaya peserta didik. Penelitian ini menggunakan metode analisis hermeneutik untuk mengungkap nilai-nilai kearifan lokal yang terkandung dalam lagu-lagu Minang dan unsur-unsur dalam proses penerapannya. Penggunaan metode ini mengutip pendapat Ricoeur (Fithri, 2013:64-74) bahwa unsur-unsur dan penerapan teori hermeneutik terdiri atas (a) objektivasi struktur teks, (b) distansiasi (perjarakan), (c) apropriasi, dan (d) analogi permainan. Metode etnografi digunakan untuk melihat dan memotret proses penerapan nilai-nilai kearifan lokal lagu Minang sebagai upaya menumbuhkembangkan literasi budaya di SD. Selain itu, Creswell (2007:68-69) mengemukakan bahwa etnografi merupakan desain penelitian kualitatif. Pada desain ini peneliti menggambarkan dan menafsirkan pola belajar nilai-nilai, perilaku, keyakinan, dan bahasa dari kelompok berbagi budaya (culture-shared) baik sebagai proses dan hasil penelitian. Etnografi melibatkan perluasan pengamatan terhadap kelompok melalui kolaboratif observasi yakni peneliti terlibat langsung dalam kehidupan sehari-hari warga sekolah yang terdiri dari kepala sekolah, guru-guru dan peserta didik, mengamati dan mewawancarai kelompok partisipan. Pada etnografer ini dipelajari makna perilaku, bahasa, dan interaksi berbagai budaya.

\section{HASIL}

Hasil penelitian menggunakan analisis hermeneutik menunjukkan bahwa lagu-lagu Minang, seperti lagu Minangkabau memiliki 7 nilai-nilai edukatif dan lagu Kampuang nan Jauah di Mato memiliki 6 nilai-nilai edukatif. Kedua lagu tersebut memiliki 13 nilai-nilai edukatif. Setelah dilakukan analisis untuk melihat kesamaan dan perbedaan arti masing-maing nilai-nilai tersebut, baik dari segi leksikal maupun arti secara denotatif dan konotatif, ditemukan 9 nilai-nilai eduaktif, yakni (1) Ketuhanan (syarak atau agamo); (2) kecintaan terhadap ranah Minang; (3) persaudaraan dan gotong-royong; (4) kesatuan dan kebersamaan; (5) musyawarah dan mufakat; (6) adil dan damai; (7) keteguhan hati; (8) waspada; dan (9) disiplin (Desyandri, 2015: 140141). Nilai-nilai edukatif lagu Minang tersebut merupakan nilai-nilai kearifan lokal Minang yang terkristalisasi ke dalam lagu-lagu Minang. Nilai-nilai keraifan lokal tersebut sangat bermanfaat dan dapat dijadikan sebagai pedoman dalam mengarahkan pikiran, perasaan atau keinginan, dan perilaku peserta didik, serta dapat juga dijadikan sebagai sarana lierasi budaya sehingga dapat mewujudkan karakter peserta didik yang beradat, beradab, berkarakter.

Pembelajaran dan implementasi nilai-nilai kearifan lokal Minangkabau yang telah dikemukakan sebelumnya dibelajarkan oleh guru-guru SD Kota Padang mengacu pada Rencana Pelaksanaan Pembelajaran (RPP) lagu-lagu Minang berbasis Literasi Budaya. Pertama, RPP mengacu pada Permendiknas No. 41 Tahun 2007 dinyatakan bahwa pelaksanaan pembelajaran merupakan implementasi dari RPP. Pelaksanaan pembelajaran meliputi kegiatan pendahuluan, kegiatan inti dan kegiatan penutup. Paparan ini difokuskan pada kegiatan inti pembelajaran. Kedua, tahapan pembelajaran Gerakan Literasi Sekolah (GLS) menurut Kemendikbud (2016) yang terdiri atas (1) tahap pembiasaan, yakni penumbuhan minat peserta didik terhadap lagu-lagu Minang dan nilai-nilai kearifan lokal yang terkandung di dalamnya; (2) tahap pengembangan, yakni mengembangkan kemampuan memahami lagu-lagu Minang dan mengaitkan dengan pengalaman pribadi, berpikir kritis, dan mengolah kemampuan komunikasi secara efektif dengan menerapkan nilai-nilai kearifan lokal yang terkandung di dalamnya; dan (3) tahap pembelajaran, yakni terkait dengan kegiatan akademis tentang mengapresiasi dan mengek- 
spresikan lagu-lagu Minang dan menerapkan nilainilai kearifan lokal yang terkandung di dalamnya.

Secara garis besar pengintegrasian pembelajaran lagu-lagu Minang dengan literasi budaya digambarkan sebagai berikut. Pertama, eksplorasi yang terdiri atas (a) guru melibatkan peserta didik mencari informasi yang luas dan dalam tentang lagu-lagu Minang yang dipelajari dengan menerapkan prinsip alam takambang jadi guru dan belajar dari aneka sumber; (b) guru memajang notasi dan lirik lagu di depan kelas dan membelejarkannya dengan menggunakan media berupa alat musik sederhana, seperti recorder, pianika, atau keyboard; (c) guru memfasilitasi terjadinya interaksi antarpesertadidik serta antara peserta didik dengan guru, lingkungan, dan sumber belajar lainnya. Interaksi tersebut dapat dilakukan dengan mengajukan dan menanggapi pertanyaan seputar lagu-lagu Minang yang dipelajari; (d) guru melibatkan peserta didik secara aktif dalam setiap kegiatan pembelajaran; (e) memfasilitasi peserta didik untuk mengapresiasi dan mengekspresikan lagu-lagu Minang, baik di kelas, studio, maupun di lapangan. Kegiatan ini bisa dilakukan dengan mengidentifikasi pencipta, nada dasar, tanda tempo, notasi, dan lirik lagu-lagu Minang dengan menggunakan aneka sumber belajar, baik dalam bentuk buku maupun sumber internet.

Kedua, elaborasi yang terdiri atas (a) membiasakan latihan pemanasan dengan menyuarakan solmisasi; (b) membiasakan peserta didik membaca notasi lagu Minang; (c) menyanyikan lirik lagu; (d) Memfasilitasi peserta didik melalui pemberian tugas dan diskusi untuk memunculkan gagasan baru terkait dengan lagu-lagu Minang, baik secara lisan maupun tertulis; (e) memberi kesempatan untuk berpikir, menganalisis, menyelesaikan masalah, dan bertindak dengan percaya diri; (f) Memfasilitasi peserta didik dalam pembelajaran kooperatif dan kolaboratif; (g) Memfasilitasi peserta didik berkompetisi secara sehat untuk meningkatkan prestasi belajar; dan (h) memfasilitasi peserta didik mengimplementasikan dan membiasakan penerapan nilai-nilai kearifan lokal yang terkandung dalam lagu-lagu Minang secara berkelanjutan. Tugas dan diskusi diarahkan untuk mengelaborasi nilai-nilai kearifan lokal yang terkandung dalam lagu-lagu Minang dan penerapannya dalam kehidupan sehari-hari. Pembelajaran dan penampilan lagu-lagu Minang membutuhkan pemodelan dan latihan secara berulangulang agar lagu tersebut dapat ditampilkan dengan baik dan benar mengacu pada karaktersitik pembelajaran seni musik, seperti pemanasan, baik suara maupun alat musik (fingering), melakukan latihan menurut bagian-bagian lagu (latihan per kalimat atau bait lagu secara berulang-ulang). Peserta didik dilibatkan dalam mengatur dan menata penampilan lagu Minang, termasuk penentuan konduktor, dirigen, posisi bernyanyi, koregrafi, penyesuaian posisi ketika berada di panggung, dan kostum yang digunakan ketika penampilan. Latihan bernyanyi atau memainkan lagu-lagu Minang dilakukan secara berkelompok dan mengutamakan kolaborasi serta kerjasama pada masing-masing kelompok. Masingmasing kelompok berkompetisi secara sehat untuk mempersiapkan sebuah penampilan lagu-lagu Minang.

Ketiga, konfirmasi yang terdiri atas (a) memberikan umpan balik positif dan penguatan dalam bentuk lisan, tulisan, isyarat, maupun hadiah terhadap keberhasilan peserta didik dalam menampilkan dan menerapkan nilai-nilai kearifan lokal (literasi budaya) lagu-lagu Minang; (b) Memberikan konfirmasi terhadap hasil eksplorasi dan elaborasi tentang lagu-lagu Minang dan nilai-nilai kearifan lokal lagu-lagu Minang. Kegiatan penutup yang terdiri atas (a) bersama-sama dengan peserta didik dan/atau sendiri membuat rangkuman atau simpulan pelajaran tentang nilai-nilai kearifan lokal yang terkandung dalam lagu-lagu Minang sebagai sarana literasi budaya dan langkah-langkah melakukan penampilannya; (b) melakukan penilaian dan/ atau refleksi agar nilai-nilai kearifan lokal sebagai sarana literasi budaya untuk dapat diterapkan dan dibudayakan, baik ketika berada di sekolah maupun di lingkungan masyarakat; (c) memberikan umpan balik terhadap proses dan hasil pembelajaran tentang pentingnya mengapresiasi dan mengekspresikan lagu-lagu Minang dan menerapkan nilai-nilai kearifan lokal sebagai sarana literasi budaya yang terkandung di dalam lagu-lagu Minang tersebut; (d) merencanakan kegiatan tindak lanjut dalam bentuk pembelajaran remedi, program pengayaan, layanan konseling dan/atau memberikan tugas baik tugas individual maupun kelompok sesuai denganhasil belajar peserta didik; dan (e) menyampaikan rencana pembelajaran pada pertemuan berikutnya.

\section{PEMBAHASAN}

Pemahaman dan pengimplementasian nilainilai kearifan lokal lagu-lagu Minang pada proses 
pembelajaran seni musik di SD mengikuti langkah dan karakteristik penguasaan seni musik. Pembelajaran diarahkan untuk mengidentifikasi dan membudayakan nilai-nilai kearifan lokal yang terkandung pada lagu. Hal ini sejalan dengan pandangan Desyandri (2017: 27) yang mengemukakan bahwa guru pembelajaran seni musik memberikan kesempatan kepada peserta didik untuk mengapresiasi dan mengekspresikan dirinya dalam menyanyikan lagulagu Minang, serta berupaya menstimulus peserta didik untuk mengidentifikasi kandungan nilai-nilai kearifan lokal lagu-lagu Minang. Lebih lanjut langkah-langkah dalam proses pembelajaran lagu Minang dikemukakan Desyandri (2018: 16-17) bahwa proses internalisasi dan pembudayaan nilai-nilai kearifan lokal Minang mengikuti tahapan, yaitu: (1) Apresiasi lagu (songs appreciation proccess). Peserta didik mengenal dan menghargai lagu-lagu Minang sebagai lagu-lagu yang mencerminkan nilai-nilai kearifan lokal Minangkabau; (2) Menirukan lagu (immitating the songs). Peserta didik mengamati dan menyanyikan irama lagu Minang dengan benar dan memunculkan rasa musikalitas; (3) mengekspresikan lagu (songs expression). Peserta didik menyanyikan lagu Minang dengan benar dan tepat; (4) Mengidentifikasi dan memahami makna nilainilai kearifan lokal (idetification and understanding the meaning of local wisdom values). Peserta didik bekerjasama untuk mengidentifikasi dan memahami makna nilai-nilai kearifan lokal lagu-lagu Minang; dan (5) Mengimplementasikan nilai-nilai kearifan lokal (implementation the local wisdom values). Peserta didik menangkap pesan-pesan moral berupa nilai-nilai kearifan lokal lagu-lagu Minang untuk diterapkan dan diimplementasikan pada lingkungan sekolah maupun lingkungan rumah atau masyarakat. Proses penerapan dan pengimplementasian nilai-nilai kearifan lokal Minang sekaligus dijadikan sebagai sarana literasi budaya.

Menyikapi nilai-nilai yang terkandung dalam lagu-lagu Minang yang memiliki pesan atau nasehat dan bersifat menuntun individu dan masyarakat Minangkabau agar melahirkan pola pikir, tindakan, dan perilaku yang sesuai dengan norma dan etika adat Minangkabau merupakan nilai-nilai kearifan lokal yang bersifat mendidik (memberikan didikan), sehingga nilai-nilai yang terkandung dalam lagulagu Minang dapat dikatakan sebagai nilai-nilai edukatif yang dapat dimanfaatkan sebagai sarana literasi budaya sehingga peserta didik memiliki kecakapan hidup menuju kehidupan yang aman, tenteram, adil, dan damai.

Adat Minangkabau berisikan hal-hal mendasar, seperti: falsafah Adat Basandi Syarak-Syarak Basandi Kitabullah (ABS-SBK) dan Alam Takambang Jadi Guru. Inti sari nilai-nilai dasar ABS-SBK tersebut menjelaskan bahwa adat Minangkabau bersendikan syari'at dan syari'at bersendikan kitabullah (Alquran). Adat Minangkabau menyandarkan diri pada ajaran agama Allah yakni Islam yang memegang teguh Alquran dan Hadis Rasulullah. Nilainilai dasar tersebut dijadikan sebagai pedoman dasar untuk mewujudkan masyarakat Minangkabau yang aman dan makmur secara lahir dan batin, berbudi luhur, berakhlak mulia, dan diridai Allah Swt, sedangkan Alam Takambang Jadi Guru, menurut Hakimy (2004:2) bahwa alam yang terkembang sebagai ciptaan Allah dapat dipelajari dengan seksama dan merupakan sumber pengetahuan, pada ahirnya dapat mengarahkan dan memberikan pedoman bagi masyarakat dalam melahirkan tindakan atau perilaku yang beradat, beradab, dan berkarakter.

Falsafah di atas membuktikan bahwa secara ideal adat Minangkabau telah memberikan bekal pengetahuan nilai-nilai kearifan lokal bagi orang Minang sehingga memiliki kecakapan dalam mengarungi kehidupan sehari-hari, baik kehidupan individu maupun kehidupan bermasyarakat. Nilainilai kearifan lokal tersebut dijadikan sebagai sarana edukatif bagi orang Minang untuk mewujudkan tujuan adat Minangkabau, yakni membentuk orang Minang yang berbudi luhur, berbudaya, dan beradab. Pembudayaan nilai-nilai adat Minangkabau telah dilakukan secara turun-temurun dengan berbagai cara. Dalam masyarakat Minangkabau, salah satu cara yang digunakan adalah melalui seni pertunjukan atau kesenian Minang, seperti yang dikemukakan Amir (2011:76) bahwa "adat-istiadat merupakan aneka kelaziman dalam suatu nagari. Kelaziman ini pada umumnya menyangkut pengejawantahan unjuk rasa seni budaya masyarakat, seperti acara-acara keramaian anak nagari (generasi muda), seperti pertunjukan randai, saluang, aneka tari-tarian, dan aneka ragam kesenian. Amir menambahkan, bahwa kebanyakan adat atau nilai-nilai sopan-santun, basa-basi, serta tata krama pergaulan termasuk dalam klasifikasi "adat-istiadat".

Salah satu di antara jenis kesenian yang ada di Minangkabau adalah lagu-lagu Minang atau dikenal juga dengan sebutan lagu-lagu Minang lamo (lama). 
Lagu-lagu Minang merupakan ungkapan perasaan dan pemikiran seniman Minang yang dituangkan ke dalam bentuk musik dan lagu yang mengandung nilai-nilai kearifan lokal Minang dan menggambarkan kondisi realitas yang terjadi di masyarakat, serta proses aktualisasi nilai-nilai yang terkandung dalam adat Minangkabau. Nilai-nilai kearifan lokal tersebut dijadikan sebagai pedoman dalam melahirkan tindakan dan perilaku yang mencerminkan karakter orang Minang. Barendregt (2002:416) mengatakan bahwa: Minang songs, provides one of the avenues through which identification as Minangkabau is experienced, defined, and consumed internally. It constructs a Minangkabau sensibility "by depicting a recognizable landscape through the use of metaphors" related to migration and the homeland.

Lagu-lagu Minang dapat mengidentifikasikan adat budaya Minangkabau yang dianut, didefinisikan, dandikonsumsisecara internal serta dapat membangun serta menggambarkan perasaan tentang keindahan alam yang dapat dikenalimelalui penggunaanmetaforaterkait dengan ranah Minang dan kebiasaan atau tradisi merantau. Lagu-lagu Minang lebih dari sekedar menceritakan tentang kerinduan terhadap alam Minangkabau, bahkan merupakan upaya masyarakat untuk berbaginilai-nilai moral. Hal tersebut senada dengan pendapat Hajizar (2012) yang menyatakan bahwa lagu-lagu Minang berangkat dari resepsi nilai-nilai sosial masyarakat. Dengan demikian, lagu-lagu Minang dapat digambarkan sebagai sebuah keintiman atau kedekatan dengan budaya Minangkabau, seperti yang dikemukakan Fraser (2011) dalam Desyandri (2016) mengemukakan bahwa, "Minang songs is a form of cultural intimacy, one that allows the Minangkabau to recognize themselves within the nation as distinct from its other constituents". Lagu-lagu Minang merupakan sebuah kedekatan budaya yang mencirikan dan sekaligus membedakan budaya Minang dengan budaya daerah lain.

Lagu-lagu Minang memiliki dua unsur pokok, yakni unsur musik dan lirik. Pertama, unsur musik lagu-lagu Minang memiliki kekhasan Minangkabau. Lagu-lagu Minang memiliki beragam alat musik yang khas Minang, seperti: talempong, gandang, bansi, saluang, rabab, dan kecapi. Sebagai sebuah genre pop, musik Minang mengalami akulturasi dengan musik modern, sehingga peralatan musiknya merupakan perpaduan dengan alat musik modern, seperti keyboard, electric guitar, saxo- phone, terompet. Irama dan melodi lagu-lagu Minang memiliki nuansa unik, yakni memiliki cengkok (gariniak) Minang, seperti yang diungkapkan Budiman (2011) bahwa lagu-lagu Minang disampaikan dalam alunan melodi yang kental dengan keunikan "gariniak" atau cengkok Minang.

Kedua, unsur lirik lagu-lagu Minang memiliki lirik yang berbentuk sajak dan pantun, seperti yang diungkapkan Darwis (2005) bahwa pantun pernah memegang peranan penting dalam kesenian Minangkabau. Orang Minang sering mengungkapkan perasaannya dengan pantun, berdialog, bahkan bersahutan kata. Dahulu pantun sangat dimengerti dan dihayati oleh orang Minang, termasuk anak muda, orang dewasa sampai pada orang tua, baik pria maupun wanita.

Kekuatan lagu-lagu Minang terletak pada nilai-nilai kearifan lokal yang terkandung dalam lirik lagu yang mencerminkan nilai-nilai adat Minangkabau. Budiman (2011) mengemukakan bahwa lirik memberikan indikasi bahwa pusako urang Minang $t u$, iyolah kato yang artinya pusaka orang Minang itu adalah kata. Kato bakieh (kata sindiran), kato bamukasuik (kata yang ditujukan untuk...), tanyo baalamat (pertanyaan yang jelas), manggado manghadang tampuak (hal-hal yang tepat sasaran), balaia manghadang pulau (upaya untuk menyelesaikan petualangan). Setiap kata ini memiliki maksud dan tujuan tertentu. Di samping itu, lirik lau-lagu Minang memiliki nilai-nilai kearifan yang santun dan menuntun. Hal ini juga ditemukan oleh Desyandri (2015) bahwa dari dua lagu Minang (lagu Minangkabau dan Kampuang nan Jauah di Mato) terkandung 9 nilai-nilai edukatif, yaitu ketuhanan (syara' atau agamo), kecintaan terhadap ranah minang, persaudaraan dan gotong royong, kesatuan dan kebersamaan, musyawarah dan mufakat, adil dan damai, keteguhan hati, waspada, dan disiplin.

Selain kekhasan musik dan nilai-nilai yang terkandung dalam lirik lagu-lagu, lagu-lagu Minang terbukti sangat dekat dengan pendengar atau masyarakat pendukungnya. Hal ini terlihat dari kepopuleran lagu-lagu Minang yangtidak hanya di wilayah Minangkabau, akan tetapi beberapa lagu tersebut telah dikenal secara nasional hingga ke manca negara dan bahkan dapat dikatakan bahwa beberapa lagu Minang tergolong lagulagu yang melegenda. Kepopuleran dan kedekatan lagu-lagu Minang dengan masyarakat pendukung 
menandakan bahwa pesan nilai-nilai yang terkandung dalam lagu-lagu Minang diterima dan hidup di hati masyarakat Minangkabau. Musik dan lirik lagu-lagu Minang mengedukasi pendengar atau pendukungnya untuk selalu mengikuti nilai-nilai adat Minangkabau dan memperlihatkan perilaku yang berbudi luhur, bertutur kata yang sopan dan santun, cinta kampung halaman, dan memberikan kesadaran untuk selalu menjunjung tinggi budaya sendiri (Desyandri, 2015).

Berdasarkan hasil dan pembehasan penelitian yang telah dikemukakan sebelumnya, menjadikan peran pendidikan dan sekolah sangat dominan dalam menumbuhkembangkan gerakan literasi budaya, yakni menjadikan nilai-nilai kearifan lokal sebagai sarana literasi budaya. Pendidikan dan kebudayaan merupakan dua hal yang tidak dapat dipisahkan dan saling terkait satu sama lain. Dengan arti kata, bahwa pendidikan tidak terlepas dari kebudayaan dan begitupun kebudayaan tidak terlepas dari pendidikan. Pandangan ini memerlukan tindak lanjut untuk mensinergikan pendidikan dan kebudayaan. Pendidikan memiliki peranan penting untuk menanamkan nilai-nilai kearifan lokal yang terkandung dalam lagu daerah setempat, khususnya lagu-lagu Minang.

Pendidikan sebagai proses pembudayaan bukan hanya merupakan proses transformasi pengetahuan yang terfokus pada penguasaan kemampuan intelektual semata, tetapi juga berperan mewariskan nilai-nilai positif budaya dan kearifan lokal sebagai tuntunan dalam melahirkan tindakan dan perilaku. Dengan kata lain, pendidikan seharusnya berupaya menjadikan nilai-nilai kearifan lokal budaya Minangkabau dan lagu-lagu Minang sebagai pedoman untuk melahirkan tindakan dan perilaku peserta didik. Upaya pembudayaan tersebut dapat dijadikan sebagai sarana untuk menumbuhkan dan membangun karakter peserta didik. Ditinjau dari tujuan pendidikan, Tilaar (2010:20-21) mengemukakan bahwa tujuan pendidikan bukan hanya manusia yang terpelajar tetapi manusia yang berbudaya, sehingga pendidikan dapat berfungsi sebagai proses pemberdayaan dan proses pembudayaan. Pendidikan sebagai proses pemberdayaan dan pembudayaan mengisyaratkan bahwa pendidikan memiliki tugas menumbuhkembangkan nilai-nilai positif yang terkandung dalam sebuah kebudayaan.

\section{SIMPULAN DAN SARAN}

\section{Simpulan}

Pelaksanaan pembelajaran yang bermakna di sekolah dasar dapat dilakukan dengan menggabungkan dan menyisipkan nilai-nilai kearifan lokal sebagai sarana literasi budaya. Pada lagu-lagu Minang ditemukan nilai-niai kearifan lokal yang dapat digunakan untuk menumbuhkembangkan literasi budaya siswa yakni bersumber pada unsurunsur dalam lagu. Apresiasi dan ekspresi terhadap lagu-lagu Minang dapat digunakan upaya dalam penerapan nilai-nilai kearifan lokal di kehidupan sehari-hari peserta didik, baik ketika berada di lingkungan sekolah maupun di lingkungan rumah atau masyarakat. Selain itu apresiasi dan ekspresi juga merupakan upaya pembudayaan nilai-nilai kearifan lokal budaya Minangkabau. Peserta didik didekatkan kembali dengan budaya lokal untuk menghindarkan peserta didik dari ketercerabutan terhadap budaya mereka sendiri.

\section{Saran}

Berdasarkan hasil penelitian maka disarankan kepada guru, khususnya guru seni musik dan Budaya Alam Minangkabau (BAM) agar selalu menstimulus dan mengarahkan peserta didik untuk mengidentifikasi, menyosialisasikan, dan membudayakan, serta mengimplementasikan nilai-nilai kearifan lokal Minangkabau melalui pembelajaran tentang lagu-lagu daerah kuhsusnya lagu Minang untuk menumbuhkembangkan literasi budaya mereka. Saran kepada kepala sekolah, agar senantiasa memberikan contoh sikap tauladan yang sesuai menurut nilai-nilai kearifan lokal adat budaya Minangkabau, mengapresiasi dan menyediakan sarana pendukung terhadap kegiatan sekolah yang berhubungan dengan penampilan atau pementasan lagu-lagu Minang, baik kegiatan yang dilaksanakan dalam pembelajaran (seni musik) maupun kegiatan ekstrakurikuler, serta mengikutsertakan peserta didik dalam kegiatan lomba lagu Minang. Saran kepada pemerintah, dalam hal ini Dinas Pendidikan Kota Padang agar senantiasa mendukung dan mengapresiasi pembudayaan nilai-nilai kearifan lokal lagu-lagu Minang dalam bentuk kebijakan-kebijakan untuk mewadahi kebermanfaatan dan pentingnya pembudayaan nilai-nilai adat budaya Minangkabau bagi kemajuan pendidikan di wilayah Kota Padang. 


\section{DAFTAR RUJUKAN}

Amir M.S. 2017. Adat Minangkabau: Pola hidup dan tujuan hidup orang Minang. Jakarta: Citra Harta Prima.

Amir M.S. 2011. Adat Minangkabau: Pola hidup dan tujuan hidup orang Minang. Edisi Revisi. Jakarta: Citra Harta Prima.

Astuti, K.S. 2010. Shaping morality through music learning in formal schools in Indonesia: An evaluation study. Artikel disajikan pada Asia Pasific Network for Moral Education 5th dalam Annual Conference Interdisciplinary Moral Education in Asia's Globalising Societies; Concept and Practices, Japan, Nagasaki University, 20 November.

Barendregt, B. 2002. The Sound of 'Longing for Home': Redefining A Sense of Community Through Minang Popular Music. Journal Bijdragen tot de Taal-, Land-en Volkenkunde, 158(3), 411-450.

Budiman, S. 2011. Lagu Minang Baru Muncul di Era 70-an. Padang: Harian Haluan Padang, hlm 23.

Darwis. 2005. Tafsir Pantun Minang I. (Online), http://www.cimbuak.net/content/ view/655/5/1/1/, diakses pada 22 Januari 2012

Desyandri. 2015. Nilai-nilai Edukatif Lagu-lagu Minang untuk Membangun Karakter Peserta Didik. Jurnal Pembangunan Pendidikan; Fondasi dan Aplikasi, 3(2), 126-141.

Desyandri. 2016. Interpretasi Nilai-nilai Lagu Kambanglah Bungo untuk Membangun Karakter Peserta Didik; Suatu Analisis Hermeneutik. Jurnal Komposisi Pendidikan Bahasa, Sastra, dan Seni,1(1), 37-51.

Desyandri. 2017. Peran Warga Sekolah dalam Pembudayaan Nilai-nilai Edukatif Lagu-lagu Minang Melalui Gerakan Literasi di Sekolah Dasar. Makalah disajikan dalam Seminar Nasional Pembelajaran Literasi Lintas Disiplin Ilmu Ke-SD-an, ISBN: 978-602-619994-0-4, 1 (1), 15-29.

Desyandri. 2018. Internalization of Local Wisdom Values Through Music Art as Stimulation of Strengthenning Character Education in Early Childhood Education; A Hermeneutic Analysis and Ethnographic Studies. Artikel disajikan pada International Conference of
Early Childhood Education (ICECE) Advances in Social Science, Education and Humanities Research (ASSEHR), 169, 13-16.

Effendy, M. 2017. Materi Pendukung Literasi Budaya dan Kewargaan. Jakarta: Kementerian Pendidikan dan Kebudayaan.

Hajizar. 2012. Lagu Padang Dulu dan Kini. Artikel. (Online), (http://albiouna.com/umum/lagupadang-dulu-dan-kini), diakses pada 3 Maret 2014.

Hakimy, I. 2004. Rangkaian mustika adat basandi syarak di Minangkabau. Bandung: Rosda Karya

Hoffman, T. K. 1991. Cultural Literacy Is More Than Reading and Writing. A Review Essay. Journal International Social Science Review, $66(1), 33-36$.

Kartawinata, A. M. 2011. Meretas Kearifan Lokal di Tengah Modernisasi dan Tantangan Pelestarian. Jakarta: Kementerian Kebudayaan dan Pariwisata R.I.

Kemendikbud. 2016. Kajian dan Pedoman Penguatan Pendidikan Karakter (PPK). Kemendikbud: Jakarta.

Kemendikbud. 2016. Gerakan Literasi untuk Tumbuhkan Budaya Literasi. Media Komunikasi dan Informasi "Jendela" Pendidikan dan Kebudayaan. Jakarta: Kemendikbud.

Kemendikbud. 201). Gerakan Literasi Nasional: Materi Pendukung Literasi Budaya dan Kewarganegaraan. Jakarta: Kemendikbud.

Naim, M. 2003. Konflik dan konsensus antara adat dan syara' di Minangkabau dalam reaktualisasi Adat Basandi Syara', Syara' Basandi Kitabullah. Padang: PPIM.

Riadi, S. 2014 . Lulus UN, pelajar di Padang malah tawuran. (Online), (http://http://www.republika.co.id/berita/nasional/nusantara-nasional/12/05/26/m4mtqg), diakses 10 Juni 2014 .

Sairin, S. 200). Perubahan sosial masyarakat Indonesia: Perspektif antropologi. Yogyakarta: Pustaka Pelajar Offset.

Tilaar, H.A.R. 2010. Paradigma baru pendidikan nasional. Jakarta: Rineka Cipta.

Zainuddin, M. 2010. Pelestarian dan eksistensi dinamis adat Minangkabau. Yogyakarta: Ombak. 